\title{
Research on the Correlation between Capitalized R\&D Expenditure and Enterprise Performance Research Based on Statistical Analysis Tools
}

\author{
Yajie Zhao $^{1 *}$ \\ ${ }^{1}$ Department of Accounting, Beijing Jiaotong University, Beijing, China
}

\begin{abstract}
Innovation is the source of power for the development of an enterprise. The enterprise aims to increase investment in research and development to maintain technological innovation capabilities, thereby enhancing its own competitive advantage. In order to explore the impact of capitalization intensity on corporate performance, this paper selects 2,829 Chinese non-financial listed companies from 2008 to 2020 as research samples, establishes a regression model of R\&D expenditure capitalization intensity and corporate performance, and conducts multiple linear regression analysis. The research in this paper finds that the capitalization of R\&D expenditure has both a value depreciation effect and a value appreciation effect. From the direct impact point of view, the accounting treatment of capitalization of R\&D expenditure reduces the company's "tax-saving" cash flow and affects the company's internal resource allocation, thereby reducing the current financial performance; and from the perspective of future effects, capitalized $R \& D$ expenditure has passed to the market The signal of $R \& D$ "success", the higher the degree of capitalization of $R \& D$ expenditure, the stronger the value-added ability of $R \& D$ expenditure in the current period and in the future period.
\end{abstract}

\section{Introduction}

$\mathrm{R} \& \mathrm{D}$ activities have gradually become more important in business management. Capitalization of $R \& D$ expenditure can convey the company's innovation information to external investors, thereby enhancing market expectations of the company. However, R\&D activities will consume a lot of manpower, material resources and financial resources, change the current allocation of resources, and have a certain impact on business operations.

With the growth of R\&D investment, the impact of $R \& D$ projects on company operations is increasing, and the corresponding accounting information has gradually attracted the attention of stakeholders. Article 38 of the International Accounting Standards stipulates that research expenditures are regarded as expenses and asset development expenditures shall be capitalized. In order to align with international accounting standards, listed companies in Shanghai and Shenzhen began to implement new accounting standards in January 2007. The regulations on investment in R\&D activities have been changed from full expense to conditional partial capitalization. Domestic scholars pay more attention to the relationship between the intensity of $R \& D$ investment and corporate performance, but there are fewer targeted researches on R\&D capitalization. It is also worth discussing whether the changes in R\&D expenditure accounting are reasonable. This article takes the A-share non-financial listed companies that disclosed R\&D expenditures from 2008 to 2020 as a sample, and analyzes the mechanism of the accounting treatment of $\mathrm{R} \& \mathrm{D}$ expenditure capitalization on corporate performance from both the company's current financial performance and corporate value.

\section{Literature review and research hypotheses}

R\&D investment in innovation is an important guarantee for an enterprise to obtain and maintain its competitive advantage in the market. Research by Hu Lixin and Hou Lijuan (2012 $)^{[1]}$ shows that R\&D investment is significantly positively correlated with Tobin's Q, and the impact of R\&D investment on Tobin's $Q$ is lagging. Paula \& Silva $(2018)^{[2]}$ pointed out that corporate R\&D investment is not only negatively correlated with current corporate financial performance, but also with future corporate financial performance. However, Landry \& Callimaci $(2003)^{[3]}$ researched that the capitalization of R\&D expenditure is a tool for companies to carry out earnings management. The higher the company's ROE level, the lower the possibility of capitalization of R\&D expenditure. Existing studies still have differences on the relationship between the capitalization of $\mathrm{R} \& \mathrm{D}$ expenditure and corporate performance. This may be due to regional differences and changes in China's policies,

\footnotetext{
* Corresponding author: 13020610889@163.com
} 
or different choices within companies for this accounting treatment. This article will be based on the predecessors, further study the relationship between the two and enrich the research path.

According to the income tax system, the expense of R\&D expenditure can achieve tax-saving cash flow in the current period, and the tax incentives for capitalization can only be amortized over the period of use of intangible assets. Assuming that the corporate income tax will not change within a certain period of time, the current enterprise value for capitalization treatment should be higher than the value of the enterprise that chooses expense treatment. In addition, in order to achieve results in R\&D activities, a large amount of manpower, material and financial resources must be invested, which will occupy the economic resources of the enterprise to a certain extent, which will have negative impact on the current enterprise performance. The hysteresis of the R\&D project itself makes it unable to immediately bring considerable economic benefits to the enterprise. Instead, it will cause a certain degree of decline in the performance in the current period due to the change in the allocation of enterprise resources. The impact mechanism of the capitalization of $\mathrm{R} \& \mathrm{D}$ expenditure on corporate performance is mainly reflected in two aspects: one is to directly affect the intertemporal cash flow of the company through tax incentives, thereby affecting the current corporate performance, and the other is to affect the allocation of economic resources of the company, which has a certain impact on the investment activities of the company. Impact and then reduce corporate financial performance. Based on this, hypothesis 1 is proposed.

Hypothesis 1: The capitalization of R\&D expenditure is negatively correlated with the current corporate performance, that is, the higher the capitalization ratio, the lower the current corporate financial performance.

In reality, if a company produces expected economic benefits due to the success of its R\&D project, rational investors will find information in the financial statements and trust the company. This is reflected in the company's stock price and market value. The capitalization of $R \& D$ expenditure reflects to a certain extent that R\&D activities have a high probability of obtaining results, which makes the outside world full of confidence in the company. So the market value of the company will also be improved.

Eberhart et al. (2004) ${ }^{[4]}$ found that companies with strong innovation strength have long-term positive excess returns. Lev and Sougiannis (1996) ${ }^{[5]}$ pointed out that the capitalization of $R \& D$ expenditure is not only related to the current value of the company, but also affects the value of the company in the future. Based on this, hypothesis 2 is proposed.

Hypothesis 2: Due to the "signaling" effect, the capitalization of $\mathrm{R} \& \mathrm{D}$ expenditure is positively correlated with the current market value, that is, the higher the capitalization ratio, the stronger the current value appreciation effect.

\section{Research design}

\subsection{Data source and sample selection}

On January 1, 2007, China's "Accounting Standards for Business Enterprises" converged with the official international standards, which had a broad and significant impact on the accounting profession. In the same year, the relevant content of the income tax law was issued, and the relevant policies for the deduction of R\&D expenses were issued the following year. Therefore, this paper sets the research period as after 2007 , that is, from 2008 to 2020 . The data sources required by the research include CSMAR, iFinD to ensure the reliability of the basic data.

The 2008-2020 consolidated financial statement data of China's A-share listed companies is selected as the initial sample, and it is screened as follows: a. All financial sector listed companies were excluded from the sample; b. In order to improve the quality of empirical testing and reduce error, companies with outlier assetliability ratios are eliminated; c. In order to avoid the influence of outliers, the samples of ST and *ST companies are excluded. All continuous variables were processed and analyzed according to the $1 \%$ standard, and finally 11604 company-annual samples, totaling 2829 companies, were processed and analyzed using EXCEL and stata15.0 statistical analysis software.

\subsection{Variable design}

\subsubsection{R\&D expenditure capitalization intensity}

This paper studies the capitalization intensity of R\&D expenditure, so the ratio of the amount of capitalization of $R \& D$ expenditure to $R \& D$ expenditure is used to measure the intensity of $R \& D$ capitalization. Based on existing research, the capitalization amount of $R \& D$ expenditure divided by the net profit of the enterprise is used as the measurement of the capitalization density of $\mathrm{R} \& \mathrm{D}$ expenditure to make the research results more robust.

\subsubsection{Business Performance}

Enterprise performance is the dependent variable. This article selects market value and financial indicators as the measurement standards. In the financial indicators, the return on total assets (ROA) and the return on net assets (ROE) are selected as the main test for research. At the same time, Tobin Q is selected as an indicator to measure market value, reflecting the reaction of market investors to innovation investment and results.

\subsubsection{Control variable}

This article controls the company characteristic variables and corporate governance variables. Company characteristic variables include: enterprise size, debt-toasset ratio, equity nature, growth ability, and operating 
cash flow. Corporate governance variables include: whether the chairman concurrently serves as the general manager, the size of the board of directors, the proportion of independent directors, and the degree of equity concentration.

Because there are certain differences in the performance of enterprises in different industries and regions, the industry and regional factors are controlled in this model. When classifying industries, the China Securities Regulatory Commission's industry classification standard (2012) is used. The manufacturing industry adopts the second-level classification, while the other industries adopt the firstlevel classification. In the control of the region, according to the National Bureau of Statistics, the economic region is divided into the eastern, central, western and northeastern four regions.

\subsection{Model design}

In order to test the above hypothesis, the following regression model is estimated:

$$
\begin{gathered}
R_{i t}\left(R_{i t}\right)=\alpha_{0}+\alpha_{1} \text { RDratio }_{i t} \\
+ \text { Control }_{i t}+\varepsilon_{i t} \\
\text { TB }_{i t}=\alpha_{0}++\alpha_{1} \text { RDratio }_{i t}+\text { Control }_{i t}+ \\
\alpha_{10} \text { GROWTH }_{i t}+\varepsilon_{i t} \\
\text { Control }_{i t}=\alpha_{2} \text { Lev }_{i t}+\alpha_{3} \text { Size }_{i t}+\alpha_{4} \text { PR }_{i t}+ \\
\alpha_{5} \text { Share }_{i t}+\alpha_{6} \text { Dual }_{i t}+\alpha_{7} \text { IDR }_{i t}+ \\
\alpha_{8} \text { DN }_{i t}+\alpha_{9} \text { CFO }_{i t}+\sum I N D_{i t}+ \\
\sum A R E A_{i t}+\sum Y E A R_{i t}
\end{gathered}
$$

Corporate performance is comprehensively measured using financial performance and market value. When Tobin's Q is used for measurement, because investors in the market have different recognition of the market value of different companies, the control variable corporate growth ability is introduced to further identify the relevance of capitalization and market value. If the coefficient of RDratio of model 1 is negative, it indicates that the intensity of $R \& D$ expenditure capitalization has a negative impact on corporate performance, that is, hypothesis 1 is true; the coefficient of RDratio of model 2 is positive, indicating that the intensity of capitalization has a positive effect on market value Impact, verify hypothesis 2 .

During the sample period, there are some unobservable company characteristics that do not change with time. Therefore, this paper uses fixed effects for regression analysis, and at the same time performs company-level cluster adjustments on the standard errors of the regression model.

\section{Empirical result analysis}

\subsection{Descriptive statistics}

Table 1 reports the descriptive statistical results of the variables. The average value of the capitalization intensity of $R \& D$ expenditure of the sample companies is about $10 \%$, the minimum value of the $R \& D$ expenditure capitalization intensity is 0 , and the maximum value of the intensity reaches $92.8 \%$, indicating that there are large differences in the capitalization intensity of $R \& D$ expenditure among the sample companies.

The average return on total assets of the sample companies is $7.5 \%$ and the average return on net assets is $4.7 \%$, it can be seen that the main variable index is at the normal level. Other indicators are basically in line with the financial status of the operating companies. The large standard deviation of Tobin's $Q$ indicates that the value of each enterprise in the capital market is quite different, which is mainly caused by the information asymmetry between investors and management. The descriptive statistical characteristics of control variables are basically consistent with existing studies.

Table 1. Descriptive Statistics

\begin{tabular}{ccccccccc}
\hline & Obs & Mean & SD & Min & P25 & Median & P75 & Max \\
\hline RDratio & 11604 & 0.099 & 0.196 & 0 & 0 & 0 & 0.105 & 0.928 \\
RDprofitratio & 6768 & 0.108 & 0.365 & -0.176 & 0 & 0 & 0.048 & 2.776 \\
ROA & 11604 & 0.075 & 0.103 & -0.413 & 0.035 & 0.076 & 0.124 & 0.349 \\
ROE & 11604 & 0.047 & 0.060 & -0.207 & 0.018 & 0.043 & 0.077 & 0.228 \\
TBQ & 11604 & 2.365 & 1.458 & 0.912 & 1.413 & 1.910 & 2.792 & 9.072 \\
\hline
\end{tabular}

(ROA) and return on net assets (ROE) as explanatory

\subsection{Multiple regression analysis}

The previous theoretical analysis has obtained a preliminary conclusion of the correlation between the capitalization of $\mathrm{R} \& \mathrm{D}$ expenditure and corporate performance, but it is not certain whether a specific functional relationship can be established between these two variables. Therefore, the following is a multiple linear regression analysis.

Table 2 reports the results of multiple regression analysis of R\&D expenditure capitalization and corporate performance. Among them, columns (1)-(2) use capitalization ratio of $R \& D$ expenditure (RDratio) as explanatory variables, and use return on total assets variables, and control the year, industry and region. According to the results of multiple regression analysis of fixed effects, the regression coefficients of RDratio are -0.0221 and -0.0091 respectively at a significance level of $1 \%$, indicating that if the capitalization intensity of $\mathrm{R} \& \mathrm{D}$ expenditure is greater, the company's return on assets will be lower in the current period. Low means that the company's performance in the current period is weaker. Column (3) uses Tobin's Q (TBQ) as an explanatory variable to examine from the perspective of non-financial performance. This indicator reflects the expectation of investors on the capitalization of enterprises in the capital market. The influence of capitalization intensity on enterprises is further explored 
through the theory of information transmission. The regression coefficient of RDratio is 0.5378 at the $1 \%$ significance level, which proves that the intensity of capitalization has a positive impact on market value. The capitalization of $\mathrm{R} \& \mathrm{D}$ expenditure sends a positive signal to the market, and investors are optimistic about the prospects of the company, thereby increasing the value of the company.

Table 2. Multiple regression result

\begin{tabular}{|c|c|c|c|c|c|c|}
\hline & (1) & (2) & (3) & (4) & (5) & (6) \\
\hline VARIABLES & $\mathrm{ROA}_{\mathrm{i}, \mathrm{t}}$ & $\mathrm{ROE}_{\mathrm{i}, \mathrm{t}}$ & $\mathrm{TBQ}_{\mathrm{i}, \mathrm{t}}$ & $\mathrm{ROA}_{\mathrm{i}, \mathrm{t}}$ & $\mathrm{ROE}_{\mathrm{i}, \mathrm{t}}$ & $T B Q_{i, t}$ \\
\hline \multirow{2}{*}{ RDratio $_{\mathrm{i}, \mathrm{t}}$} & $-0.0221 * * *$ & $-0.0091 * * *$ & $0.5378 * * *$ & & & \\
\hline & $(-3.66)$ & $(-2.86)$ & $(4.93)$ & & & \\
\hline \multirow{2}{*}{ RDprofitratio $_{i, t}$} & & & & $-0.0078 * * *$ & $-0.0054 * * *$ & $0.1092 * *$ \\
\hline & & & & $(-3.30)$ & $(-3.84)$ & $(2.08)$ \\
\hline Observations & 11,604 & 11,604 & 11,604 & 6,768 & 6,768 & 6,768 \\
\hline R-squared & 0.2261 & 0.3479 & 0.3370 & 0.2188 & 0.3450 & 0.3465 \\
\hline F & 69.71 & 105.3 & 104.2 & 52.54 & 77.03 & 66.73 \\
\hline
\end{tabular}

\subsection{Robustness test}

We used the R\&D expenditure capitalization ratio (RDratio) as the proxy variable of the capitalization intensity of the sample companies, examined the effect of the capitalization intensity on corporate performance, and obtained results consistent with the hypothesis. In order to ensure the robustness of the benchmark regression results, we replace the proxy variable of capitalization intensity, and re-examine this effect. Refer to the existing literature and use the capitalization density (RDprofitratio) as the proxy variable of the capitalization intensity (Zhang Qianqian, 2017) ${ }^{[6]}$. The return on total assets, return on net assets and Tobin's Q are still used as dependent variables for robust testing to analyze the company's profitability and market value. The capitalization density of $\mathrm{R} \& \mathrm{D}$ expenditure is calculated by using the ratio of capitalization amount of R\&D expenditure and net profit of the enterprise to further examine the impact of intensity of capitalization of R\&D expenditure.

In the regression results of columns (4)-(6) in Table 2, the independent variable RDprofitratio coefficient is significantly negative at the $1 \%$ level for financial performance, and significantly positive at the 5\% level for the market value, which is consistent with the conclusion of the benchmark regression. That is, the intensity of capitalization of $R \& D$ expenditure has a negative impact on the current corporate performance and a positive impact on the current market value.

\section{Conclusion}

According to the above research, the accounting treatment of R\&D activities by enterprises will have a certain impact on current performance. This article makes a value judgment on the accounting treatment of enterprise capitalization from the perspective of financial and non-financial performance. The signal transmission effect has been further studied. This paper found that the higher the degree of capitalization of R\&D expenditure, the smaller the value-added effect of the current corporate financial performance.
However, because the capitalization of R\&D expenditure sends a positive signal to the market, the greater the value-added role of the current corporate value in the market. The research value of this article lies in the fact that, compared with the expense accounting treatment of R\&D expenditure, capitalization has a "signal transmission" effect, but at the same time, changes in resource allocation may cause companies to lose good investment opportunities. So overinvestment in $\mathrm{R} \& \mathrm{D}$ activities will also cause companies to fall into certain operational crisis. Therefore, companies should carefully consider investment in research and development activities and correctly measure the allocation of economic resources for business activities, so as to promote the healthy development of the company.

\section{References}

1. Hu Lixin, Hou Lijuan. Test on the relationship between R\&D investment and Tobin's Q value of listed companies. FA. ,76-77(2012)

2. F. Paula ,J. Silva. The impact of alliances and internal $R \& D$ on the firm's innovation and financial performance. BBR. ,15(2018)

3. S. Landry, A. Callimaci. The effect of management incentives and cross-listing status on the accounting treatment of R\&D spending. JIAAT. ,12,131152(2003)

4. C. Eberhart, W. F. Maxwell ,A. R. Siddique. An Examination of Long - Term Abnormal Stock Returns and Operating Performance Following R\&D Increases. JF. ,59(2004)

5. L. A ,T. S. B. The capitalization, amortization, and value-relevance of R\&D. Ind. Health,53,498504(1996)

6. Zhang Qianqian, Zhou Mingshan, Dong Zhiyong.Does Capitalization of R\&D Spending Signal the Change of Corporate Value? FR. ,176190(2017) 